\title{
DEATH RATES OF MINERS AND EX-MINERS WITH AND WITHOUT COALWORKERS' PNEUMOCONIOSIS IN SOUTH WALES
}

\author{
BY \\ R. G. CARPENTER and A. L. COCHRANE \\ With the assistance of \\ W. G. CLARKE, G. JONATHAN, and F. MOORE \\ From the Pneumoconiosis Research Unit of the Medical Research Council, Llandough Hospital, Nr. Cardiff
}

(RECEIVED FOR PUBLICATION, APRIL 1, 1955)

At present the only practical method by which a diagnosis of coalworkers' pneumoconiosis can be made in life is by means of chest radiographs. Such a diagnosis, however, merely signifies the presence of radiological abnormalities due to exposure to coal dust. Of itself, it can tell us little about pulmonary disability or future loss of expectation of life. It is thus unfortunate that the radiograph has become practically of such importance, both in relation to dust suppression and to industrial compensation, before the necessary correlations have been established, i.e., between dust concentration, time of exposure, and rate of appearance of radiological abnormality on the one hand, and the radiological category of coalworkers' pneumoconiosis, age, pulmonary disability, and loss of expectation of life on the other.

Roach (1953) has shown that a relationship exists between dust concentration, time, and the appearance of the first radiological abnormalities. Gilson and Hugh-Jones (1955) and Gilson, Higgins, and Carpenter (1956) discuss the relationship between age, radiological category, and pulmonary disability. This paper attempts the third of these correlations-the relationship between age, radiological category, and expectation of life.

The problem has been much misunderstood in the past amongst both doctors and laymen. The radiological changes in coalworkers' pneumoconiosis are particularly striking, and some doctors who tend to judge these changes by comparing them with tuberculosis, with which they are better acquainted, have sometimes given too gloomy a prognosis. Moreover, people have an understandable difficulty in differentiating between figures relating to those suffering from coalworkers' pneumoconiosis who die and figures relating to those who die from pneumoconiosis. The publicity given to the former figures and the lack of information about the latter have probably given an exaggerated picture of the seriousness of the disease from the point of view of mortality.

The literature on the effect of pneumoconiosis on mortality is somewhat limited. Fletcher (1948) pointed out that the standardized death rates of coal-miners in England and Wales for all respiratory diseases except tuberculosis, when compared with those rates for all occupied and retired males, showed a marked excess for the four periods 1900-02, 1910-12, 1921-23, and 1930-32. He also pointed out that it was the coal-miners over the age of 55 in whom this excess of deaths was seen and suggested that this excess of deaths might be due to deaths from coalworkers' pneumoconiosis. The only detailed study of death rates associated with coalworkers' pneumoconiosis is that of Stewart, Davies, Dowsett, Morrell, and Pierce (1948). They followed up 3,435 coal-miners who had been certified during life by the Silicosis Medical Board in South Wales during the period 1931-45. Their analysis suggested that for both the " early disease " group and the "advanced disease" group there was a marked reduction in survival rate as compared with the 1931 English Life Table, No. 10 (Registrar General, 1936). After 10 years it appeared that $60 \%$ of those with " early disease" and $25 \%$ of those in the "advanced" group might still be alive compared with $85 \%$ expected from the life table. This suggested that coalworkers' pneumoconiosis was associated with a marked loss of expectation of life.

Ideally, to study this problem one requires a very large complete population of miners and ex-miners, 
all of whom have been radiographed, in an area with a high prevalence of all types of coalworkers' pneumoconiosis. In addition, one needs another complete population of similar social class who have not been exposed to coal dust. The size of the population should be such that there would be sufficient deaths within one year of the radiological survey to give a clear-cut answer to the problem. The short follow-up is important since difficulties arise through people leaving the area and becoming increasingly difficult to trace.

It is highly improbable that such material will ever be available and so, as the problem is important, one is forced to see what can be deduced from the best material that is available.

\section{Material}

The population of the Rhondda Fach (a mining valley in South Wales with a population of about 30,000 ) was surveyed first in $1950-51$, when $89 \%$ of those over the age of 5 in the valley were radiographed (Cochrane, Cox, and Jarman, 1952). In 1953 the valley was re-surveyed, $91 \%$ radiographed, and particular care was taken to see what had happened to all those who were in the valley at the time of the first survey (Cochrane and others, 1955). As a result, we have a population in 1950-51 carefully defined by age and sex, the males divided into miners, ex-miners, and non-miners, and the miners and ex-miners further classified according to their pneumoconiosis category (Cochrane, Davies, and Fletcher, 1951 ; Cochrane, Fletcher, Gilson, and Hugh-Jones, 1951 ; Fletcher, 1955), together with deaths in the various groups during the interval between the two surveys. The average interval between the two surveys was determined by examining the dates of a random sample of films and was estimated as $2 \cdot 6$ years.

The material is not ideal. In the first place it is too small. This means that the life table approach is not possible as the procedure for comparing life tables based on small numbers has not been developed. Hence the analysis is confined to a study of observed and expected death rates. In addition, only about $95 \%$ of the miners and exminers were radiographed, and illness was of course one cause for failure to be radiographed. Even after a follow-up of two and a half years when difficulties in tracing people were beginning to become apparent, there were too few deaths to justify a breakdown by cause. This was, however, a minor drawback, as we were mainly interested in total effect on life and not in the mode of death of pneumoconiotics, or in how a decrease from one cause could be balanced by an increase in another.
We also had no ideal control group. The nonminers in the valley are a very small group, their numbers being particularly deficient at higher ages. We have therefore used the only other material available, the Registrar General's data for England and Wales. This is the usual standard used in calculating standardized mortality ratios. The data for England and Wales have the advantage that numbers of deaths are so large that the random errors in the expected number of deaths calculated from them can be ignored.

Our material is, however, clearly unsuitable for direct comparison with the Registrar General's figures. The latter's material consists of deaths in one year in a large complete population related to the mid-year population estimates; our material consists of deaths during a period of 2.6 years occurring in a relatively small population defined at the beginning of the period. It is clear that the population gets older and certain small changes take place in radiological category during the period of the follow-up. The radiological changes are few in number and can be ignored for the purposes of this study, while, to compare the experience of the Rhondda Fach with the national mortality experience during the follow-up period, we have worked out, from the Registrar General's published figures, the number of deaths that would have been expected in the Rhondda Fach. The method of obtaining these figures is given in the Appendix. To compare the observed with the expected number of deaths over a specified age range, we used standardized mortality ratios (S.M.R.) which are the observed number of deaths expressed as a percentage of the number expected on the basis of national age-specific rates.

\section{Results}

Table 1 gives the age and sex distribution of the population of the Rhondda Fach at the time of the first radiological survey, together with the observed

TABLE 1

DEATHS (ALL CAUSES) OBSERVED AND EXPECTED AMONGST MALES AND FEMALES IN THE RHONDDA FACH IN 1950-51

\begin{tabular}{|c|c|c|c|c|c|c|}
\hline \multirow[b]{2}{*}{ Age } & \multicolumn{3}{|c|}{ Males } & \multicolumn{3}{|c|}{ Females } \\
\hline & No. & $\begin{array}{c}\text { Observed } \\
\text { Deaths }\end{array}$ & $\begin{array}{c}\text { Expected } \\
\text { Deaths }\end{array}$ & No. & $\begin{array}{c}\text { Observed } \\
\text { Deaths }\end{array}$ & $\begin{array}{l}\text { Expected } \\
\text { Deaths }\end{array}$ \\
\hline $\begin{array}{l}5- \\
50- \\
15- \\
20- \\
25- \\
35- \\
45- \\
55- \\
65- \\
75- \\
85-\end{array}$ & $\begin{array}{r}975 \\
1,010 \\
891 \\
819 \\
1,890 \\
1,798 \\
1,557 \\
1,326 \\
823 \\
296 \\
27\end{array}$ & $\begin{array}{r}2 \\
4 \\
5 \\
5 \\
19 \\
22 \\
46 \\
98 \\
141 \\
108 \\
13\end{array}$ & $\begin{array}{r}1.5 \\
1.5 \\
2.2 \\
2.8 \\
7.9 \\
14.9 \\
37.3 \\
86.1 \\
124.0 \\
92.7 \\
15.4\end{array}$ & $\begin{array}{r}1,000 \\
1,005 \\
972 \\
887 \\
2,018 \\
1,878 \\
1,783 \\
1,397 \\
883 \\
332 \\
45\end{array}$ & $\begin{array}{r}1 \\
2 \\
4 \\
7 \\
11 \\
8 \\
28 \\
54 \\
75 \\
88 \\
25\end{array}$ & $\begin{array}{r}1.1 \\
1.0 \\
1.5 \\
2.0 \\
6.7 \\
11.8 \\
26.1 \\
50.3 \\
86.3 \\
82.9 \\
23.3\end{array}$ \\
\hline Total & 11,412 & 463 & $386 \cdot 3$ & 12,200 & 303 & 293.0 \\
\hline
\end{tabular}


deaths and the expected deaths, as obtained by the methods shown in the Appendix. It is clear that amongst males the observed number of deaths are somewhat higher than the expected number, but no such differences are apparent for the females. This is confirmed by the standardized mortality ratios for the two sexes (Table 2). This difference between the S.M.R.s of the two sexes at once suggests the possibility of some occupational factor influencing the male death rates.

TABLE 2

STANDARDIZED MORTALITY RATIOS IN THE RHONDDA FACH $1950-51$

\begin{tabular}{c|c|c}
\hline Age & Males & Females \\
\hline $20-64$ & $-190 / 149 \cdot 0=127 \cdot 5 \%$ & $108 / 96 \cdot 9=111 \cdot 5 \%$ \\
$25-74$ & $326 / 270 \cdot 2=120 \cdot 7 \%$ & $176 / 181 \cdot 2=97 \cdot 1 \%$ \\
$5-74$ & $342 / 278 \cdot 2=122 \cdot 9 \%$ & $190 / 186 \cdot 8=101 \cdot 7 \%$ \\
\hline
\end{tabular}

Before, however, examining the death rates in relation to pneumoconiosis category, a possible major source of error must be considered. It was not possible to radiograph every male, and as illness was one reason for not being radiographed it is possible for a considerable error to creep in. The " observed" and "expected" deaths for radiographed males and males not radiographed are shown in Table 3 together with their S.M.R.s and their standard errors. It will be seen that the S.M.R.s for those not radiographed are appreciably higher than those for the radiographed. Although we have a great deal of information about those who were not radiographed and corrections can be introduced to make allowance for them, we considered it more correct to present the results obtained from the radiographed population first before dealing with the corrections.

Table 4 shows the age distribution of the four male groups who were radiographed : (1) those who had never been miners ; (2) the miners and exminers whose radiographs were normal as regards coalworkers' pneumoconiosis; (3) the miners and ex-miners whose radiographs showed simple pneumoconiosis (categories 1,2 , or 3 ) or complicated pneumoconiosis (category A); (4) those miners and ex-miners whose radiographs showed advanced complicated pneumoconiosis (categories B, C, and D). In addition, Table 4 shows the expected and observed deaths for the various groups. Complicated pneumoconiosis (category A) has been included with the group of those with simple pneumoconiosis as at this stage simple pneumoconiosis is still likely to be the predominant feature from the physiological point of view. This is confirmed by physiological studies (Gilson and others, 1956). A further reason for this grouping is the fact that tomography of those with category 2 or 3 on posteroanterior films occasionally reveals areas of complicated pneumoconiosis.

Table 5 shows the S.M.R.s calculated for various age ranges of the various occupational radiological groups. It seems reasonable, when dealing with a condition like coalworkers' pneumoconiosis, to attach more importance to the age range 35-74

TABLE 3

STANDARDIZED MORTALITY RATIOS OF MALES IN THE RHONDDA FACH

\begin{tabular}{|c|c|c|c|c|c|c|c|c|c|c|c|c|}
\hline \multirow{2}{*}{$\begin{array}{c}\text { Age } \\
\text { Range }\end{array}$} & \multicolumn{4}{|c|}{ All Males } & \multicolumn{4}{|c|}{ Males Radiographed } & \multicolumn{4}{|c|}{ Males not Radiographed } \\
\hline & $\begin{array}{c}\text { Observed } \\
\text { Deaths }\end{array}$ & $\begin{array}{c}\text { Expected } \\
\text { Deaths }\end{array}$ & S.M.R. & $\begin{array}{c}\text { Standard } \\
\text { Errors }\end{array}$ & $\begin{array}{c}\text { Observed } \\
\text { Deaths }\end{array}$ & $\begin{array}{c}\text { Expected } \\
\text { Deaths }\end{array}$ & S.M.R. & $\begin{array}{c}\text { Standard } \\
\text { Errors }\end{array}$ & $\begin{array}{c}\text { Observed } \\
\text { Deaths }\end{array}$ & $\begin{array}{c}\text { Expected } \\
\text { Deaths }\end{array}$ & S.M.R. & $\begin{array}{c}\text { Standard } \\
\text { Errors }\end{array}$ \\
\hline $\begin{array}{r}20-64 \\
25-74 \\
5-74\end{array}$ & $\begin{array}{l}190 \\
326 \\
342\end{array}$ & $\begin{array}{l}149 \cdot 0 \\
270 \cdot 2 \\
278 \cdot 2\end{array}$ & $\begin{array}{l}127.5 \\
120 \cdot 7 \\
122.9\end{array}$ & $\begin{array}{l} \pm 9.25 \\
\pm 6.68 \\
\pm 6.65\end{array}$ & $\begin{array}{l}168 \\
272 \\
288\end{array}$ & $\begin{array}{l}136.9 \\
239.0 \\
246.4\end{array}$ & $\begin{array}{l}122.7 \\
113.8 \\
116.9\end{array}$ & $\begin{array}{l} \pm 9.47 \\
\pm 6.90 \\
\pm 6.89\end{array}$ & $\begin{array}{l}22 \\
54 \\
54\end{array}$ & $\begin{array}{l}12 \cdot 1 \\
31 \cdot 2 \\
31 \cdot 8\end{array}$ & $\begin{array}{l}181.8 \\
173.1 \\
169.8\end{array}$ & $\begin{array}{l} \pm 38.76 \\
\pm 23.55 \\
\pm 23.11\end{array}$ \\
\hline
\end{tabular}

TABLE 4

OBSERVED AND EXPECTED DEATHS AMONGST NON-MINERS AND MINERS AND EX-MINERS WITH AND WITHOUT PNEUMOCONIOSIS IN THE RHONDDA FACH

\begin{tabular}{|c|c|c|c|c|c|c|c|c|c|c|c|c|}
\hline \multirow{3}{*}{ Age } & \multirow{2}{*}{\multicolumn{3}{|c|}{ Non-miners }} & \multicolumn{9}{|c|}{ Miners and Ex-miners } \\
\hline & & & & \multicolumn{3}{|c|}{ Category 0} & \multicolumn{3}{|c|}{ Categories $1,2,3$, and $A$} & \multicolumn{3}{|c|}{ Categories B, C, and D } \\
\hline & No. & $\begin{array}{c}\text { Observed } \\
\text { Deaths }\end{array}$ & $\begin{array}{c}\text { Expected } \\
\text { Deaths }\end{array}$ & No. & $\begin{array}{c}\text { Observed } \\
\text { Deaths }\end{array}$ & $\begin{array}{c}\text { Expected } \\
\text { Deaths }\end{array}$ & No. & $\begin{array}{l}\text { Observed } \\
\text { Deaths }\end{array}$ & $\begin{array}{c}\text { Expected } \\
\text { Deaths }\end{array}$ & No. & $\begin{array}{c}\text { Observed } \\
\text { Deaths }\end{array}$ & $\begin{array}{c}\text { Expected } \\
\text { Deaths }\end{array}$ \\
\hline $\begin{array}{l}15- \\
20- \\
25- \\
35- \\
45- \\
55- \\
65- \\
75-\end{array}$ & $\begin{array}{r}549 \\
453 \\
669 \\
405 \\
187 \\
126 \\
53 \\
17\end{array}$ & $\begin{array}{l}2 \\
2 \\
6 \\
4 \\
3 \\
7 \\
8 \\
8\end{array}$ & $\begin{array}{l}1 \cdot 4 \\
1.6 \\
2.8 \\
3.4 \\
4 \cdot 5 \\
8 \cdot 2 \\
8 \cdot 0 \\
5 \cdot 3\end{array}$ & $\begin{array}{r}273 \\
271 \\
686 \\
630 \\
669 \\
541 \\
300 \\
91\end{array}$ & $\begin{array}{r}3 \\
3 \\
5 \\
3 \\
21 \\
40 \\
46 \\
27\end{array}$ & $\begin{array}{r}0.7 \\
0.9 \\
2 \cdot 9 \\
5 \cdot 2 \\
16 \cdot 0 \\
35 \cdot 1 \\
45 \cdot 2 \\
28 \cdot 5\end{array}$ & $\begin{array}{r}4 \\
44 \\
382 \\
522 \\
462 \\
362 \\
222 \\
49\end{array}$ & $\begin{array}{l}- \\
6 \\
10 \\
10 \\
26 \\
30 \\
16\end{array}$ & $\begin{array}{r}\overline{0.2} \\
1.6 \\
4.3 \\
11 \cdot 1 \\
23 \cdot 5 \\
33.4 \\
15.3\end{array}$ & $\begin{array}{r}-1 \\
25 \\
121 \\
137 \\
176 \\
120 \\
40\end{array}$ & $\begin{array}{r}- \\
\\
3 \\
5 \\
14 \\
25 \\
12\end{array}$ & $\begin{array}{r}\text { 二 } \\
0.1 \\
1.0 \\
3.3 \\
11.4 \\
18.1 \\
12.5\end{array}$ \\
\hline Total & 2,459 & 40 & $35 \cdot 2$ & 3,461 & 148 & $134 \cdot 5$ & 2,047 & 98 & $89 \cdot 4$ & 620 & 59 & $46 \cdot 4$ \\
\hline
\end{tabular}


TABLE 5

STANDARDIZED MORTALITY RATIOS FOR NON-MINERS AND MINERS AND EX-MINERS WITH AND WITHOUT PNEUMOCONIOSIS IN THE RHONDDA FACH

\begin{tabular}{|c|c|c|c|c|c|c|c|c|c|c|c|c|c|c|c|c|}
\hline \multirow{3}{*}{$\begin{array}{c}\text { Age } \\
\text { Range }\end{array}$} & \multirow{2}{*}{\multicolumn{4}{|c|}{ Non-miners }} & \multicolumn{12}{|c|}{ Miners and Ex-miners } \\
\hline & & & & & \multicolumn{4}{|c|}{ Category 0} & \multicolumn{4}{|c|}{ Categories $1,2,3$, and $A$} & \multicolumn{4}{|c|}{ Categories B, C, D } \\
\hline & $\begin{array}{l}\text { Ob- } \\
\text { served } \\
\text { Deaths }\end{array}$ & $\begin{array}{c}\text { Ex- } \\
\text { pected } \\
\text { Deaths }\end{array}$ & S.M.R. & $\begin{array}{l}\text { Stan- } \\
\text { dard } \\
\text { Error }\end{array}$ & $\begin{array}{c}\text { Ob- } \\
\text { served } \\
\text { Deaths }\end{array}$ & $\begin{array}{c}\text { Ex- } \\
\text { pected } \\
\text { Deaths }\end{array}$ & S.M.R. & $\begin{array}{l}\text { Stan- } \\
\text { dard } \\
\text { Error }\end{array}$ & $\begin{array}{c}\text { Ob- } \\
\text { served } \\
\text { Deaths }\end{array}$ & $\begin{array}{c}\text { Ex- } \\
\text { pected } \\
\text { Deaths }\end{array}$ & S.M.R. & $\begin{array}{l}\text { Stan- } \\
\text { dard } \\
\text { Error }\end{array}$ & $\begin{array}{c}\text { Ob- } \\
\text { served } \\
\text { Deaths }\end{array}$ & $\begin{array}{c}\text { Ex- } \\
\text { pected } \\
\text { Deat hs }\end{array}$ & S.M.R. & $\begin{array}{l}\text { Stan- } \\
\text { dard } \\
\text { Error }\end{array}$ \\
\hline $\begin{array}{l}20-64 \\
25-64 \\
25-74 \\
35-74\end{array}$ & $\begin{array}{l}22 \\
20 \\
28 \\
22\end{array}$ & $\begin{array}{l}20 \cdot 5 \\
18 \cdot 9 \\
26 \cdot 9 \\
24 \cdot 1\end{array}$ & $\begin{array}{r}107 \cdot 3 \\
105 \cdot 8 \\
104 \cdot 1 \\
91 \cdot 3\end{array}$ & $\begin{array}{l} \pm 22.88 \\
\pm 23.66 \\
\pm 19.67 \\
\pm 19.46\end{array}$ & $\begin{array}{r}72 \\
69 \\
115 \\
110\end{array}$ & $\begin{array}{r}60.1 \\
59.2 \\
104.4 \\
101.5\end{array}$ & $\begin{array}{l}119.8 \\
116.6 \\
110.2 \\
108.4\end{array}$ & \begin{tabular}{|l|} 
$\pm 14 \cdot 12$ \\
\pm 14.03 \\
\pm 10.27 \\
\pm 10.33
\end{tabular} & $\begin{array}{l}52 \\
52 \\
82 \\
76\end{array}$ & $\begin{array}{l}40 \cdot 7 \\
40 \cdot 5 \\
73 \cdot 9 \\
72 \cdot 3\end{array}$ & $\begin{array}{l}127.8 \\
128.4 \\
111.0 \\
105.1\end{array}$ & $\begin{array}{l} \pm 17.72 \\
\pm 17.81 \\
\pm 12.25 \\
\pm 12.06\end{array}$ & $\begin{array}{l}22 \\
22 \\
47 \\
47\end{array}$ & $\begin{array}{l}15.8 \\
15.8 \\
33.9 \\
33.8\end{array}$ & $\begin{array}{c}139 \cdot 2 \\
139 \cdot 2 \\
138.6 \\
139 \cdot 1\end{array}$ & $\begin{array}{r} \pm 29.69 \\
\pm 29.69 \\
\pm 20.22 \\
\pm 20.28\end{array}$ \\
\hline
\end{tabular}

than to the others, and on this basis one would say that there was no evidence that simple pneumoconiosis was associated with a decreased expectation of life. Some evidence of a trend is apparent here but before accepting it we need to examine the separate age groups in more detail. Standardized mortality ratios could be derived for each of the age-occupation-radiological groups shown in Table 4 , but since the standard errors depend both on the chance of dying and on the number of people in the group, each of these S.M.R.s would require a separate standard error to assess its significance.

A transformed death rate $\psi^{*}$ can be derived for each of the four occupational radiological groups at relevant ages (Table 6), which does not have this disadvantage. The value of $\psi$ is positive if the observed number of deaths in the group is greater than expected, zero if equal to expected, and negative if less than expected. Each $\psi$ has the same standard error of $\pm 28.7 \dagger$. Thus a single observation of $\psi$ which is greater than 57.4 indicates a significant excess in the observed number of deaths, and similarly an observation which is less than -57.4 indicates a significant reduction in the observed number of deaths in comparison with the expected number. This makes visual inspection of a table of death rates, for values which are likely to be significant, very easy, although in a large table of entries, such as Table 6, one or two apparently significant entries are to be expected by chance alone.

The following points emerge from Tables 3, 4, 5, and 6 :-

(1) The observed number of deaths among all males over 25 who were radiographed is above expectation. The S.M.R. of the group is $113.8 \pm$

\footnotetext{
* $\psi=\sqrt{n}\left(\sin ^{-1} \sqrt{\bar{p}}-\sin ^{-1} \sqrt{q}\right)$ where $n=$ number of subjects followed up, $p=$ observed percentage of deaths, and $q=$ expected percentage of deaths.

$\dagger$ Strictly the standard errors of $\psi$ are only constant if in each ageoccupation-radiological group each individual has the same chance of dying in the inter-survey period. In this case the standard error
would be \pm 28.7 as stated. The observed standard error is almost would be $\pm 28 \cdot 7$ as stated. The observed standard error is almost
identical with the theoretical value, being $\pm 27 \cdot 04$, so that the theoretical model seems to fit the data well, and the theoretical standard error has been adopted.
}

TABLE 6

TABLE OF TRANSFORMED DEATH RATES $\psi$ CORRESPONDING TO TABLE 4

\begin{tabular}{|c|c|c|c|c|}
\hline \multirow[b]{2}{*}{ Age } & \multirow[b]{2}{*}{ Non-miners } & \multicolumn{3}{|c|}{ Miners and Ex-miners } \\
\hline & & Category 0 & $\begin{array}{l}\text { Categories } 1 \text {, } \\
2,3 \text {, and } A\end{array}$ & $\begin{array}{c}\text { Categories B, } \\
\text { C, and D }\end{array}$ \\
\hline $\begin{array}{l}25- \\
35- \\
45- \\
55- \\
65- \\
75-85\end{array}$ & $\begin{array}{c}44 \cdot 0 \\
10 \cdot 1 \\
-23 \cdot 3 \\
-11 \cdot 2 \\
0 \\
38 \cdot 7\end{array}$ & $\begin{array}{r}28 \cdot 8 \\
-27.6 \\
31.0 \\
23.3 \\
1.7 \\
-9.5\end{array}$ & $\begin{array}{r}68.4 \\
61.7 \\
-8.6 \\
15.2 \\
-19.4 \\
6.3\end{array}$ & $\begin{array}{r}-* \\
42 \cdot 9 \\
23 \cdot 4 \\
22 \cdot 6 \\
47 \cdot 1 \\
-5 \cdot 1\end{array}$ \\
\hline
\end{tabular}

Overall mean of $\psi=15 \cdot 7 \pm 5.97$. Theoretical standard error of $\psi$ $= \pm 28 \cdot 7$.

* The transformation is not useful when the observed number of deaths is zero.

6.90 and this excess is confirmed as being significant in that the overall mean of $\psi$ in Table 6 is significantly greater than zero. This is not due to an excess of deaths in one group alone.

(2) Increasing radiological category seems to show a trend of increasing S.M.R. but from the values of $\psi$ in Table 6 we see that there is no definite trend of this sort in any of the age groups.

(3) Table 6 also shows that in none of the occupational radiological groups does the observed number of deaths increasingly exceed the expected number, with increasing age.

(4) Among non-miners the number is mainly near that expected, with insignificant excesses in the youngest and oldest age groups.

(5) Among those with early pneumoconiosis an excess occurs in the two youngest age groups. The number of deaths in both these groups exceeds the values expected by chance in a single observation, and it is unlikely that a pair of values as large as these would occur by chance in the same occupational radiological group and in adjoining age groups anywhere in Table 6. It therefore appears that in these two age groups the radiological changes are associated with some increased risk of death, but the risk is almost certainly not caused by the pneumoconiosis.

In the first place, the non-miners and the category Os show an excess of observed deaths over expected 
in those aged 25 to 34 . In the second place, the group of those category 1 to A consists largely of working miners at special risk to pit accidents. In fact, of the 16 deaths in this group under the age of 45 , five were from violent causes, four being due to pit accidents. But against this must be set the fact that in $195322 \%$ of deaths in England and Wales of those aged 25 to 44 were from violent causes. This illustrates the difficulty of any attempt to restrict the study to specific causes of death, in that both the observed deaths and the national death rates have to be purified. Table 5 shows that the S.M.R.s for those with early pneumoconiosis are not raised to any significant extent.

(6) There is an excess in all but the last age group among those with $\mathrm{B}, \mathrm{C}$, and $\mathrm{D}$ radiographs. The excess is not significant in any of the age groups individually, nor is the excess significant when all the age groups are taken together, as the S.M.R.s in Table 5 also show, and this can be confirmed by the occupational radiological group means calculated from the $\psi$ in Table 6.

The following information is available about those who were not radiographed at the time of the first survey :-

(1) Their age was obtained by home visiting at the time of the first survey.

(2) Their occupation was determined in two towns in the valley at the first survey, and of those remaining in all the eight towns at the time of the second survey. The proportion of non-miners to miners and ex-miners in corresponding age groups was almost identical in these two samples.

(3) The radiological category of $56 \%$ of them was obtained at the time of the second survey.

The age distribution of the lapses is unfortunate in that the lapse rates are highest in those age groups most likely to be affected by pneumoconiosis, and Table 3 shows that the number of deaths that occurred among them is not negligible. The fact that the two samples showed similar proportions of non-miners to miners and ex-miners is encouraging in that they do not lead us to think that all those lapsing who died were miners or ex-miners, but the comparison is an insensitive one for detecting the occupational group of those who died. Calculations based on those who survived to the second survey and on those who were radiographed then suggest that, for example, of those aged 65 to $74,15 \%$ were non-miners, $46 \%$ were miners and ex-miners category $0,25 \%$ were categories 1 to $\mathrm{A}$, and $14 \%$ were $\mathrm{B}, \mathrm{C}$, or $\mathrm{D}$, with similar percentages in these occupational radiological groups at other ages. Although nothing can replace the missing information concerning the lapses it seemed worth while studying what the effects of the lapses would be were they distributed among the occupational radiological groups as suggested by these data from the second survey, and the deaths that occurred among the lapses distributed in proportions based on this distribution of the lapses in the occupational radiological groups, and the observed death rates for the corresponding groups at the appropriate age. The results of these calculations were to increase the number of deaths in all groups, principally amongst miners and ex-miners category 0 , but did not suggest that we ought to modify the conclusions already drawn from the data.

The only other source of information about the lapses that suggested itself was the certified causes of death. Examination of these immediately shows they contain no specific information as to which occupational radiological group the case belonged, except for the occasional case which came to necropsy.

\section{Discussion}

These results will be considered by some people as somewhat surprising in that we have found no evidence that simple pneumoconiosis, during the period of observation, was associated with any decreased expectation of life in any of the older age groups. We have not, of course, excluded the possibility of some small increase or decrease in expectation of life. Our results are, however, in agreement with those of Gough and Heppleston (1955) that "simple pneumoconiosis is very rarely fatal ".

We have, too, found only suggestive evidence that progressive massive fibrosis is a lethal disease, but this is perfectly compatible with the high prevalence (about 15\%) of P.M.F. found in the higher age groups in the Rhondda Fach (Cochrane and others, 1952).

All these results differ strikingly from those of Stewart and others (1948). The extent of the difference is shown in Table 7. Their material consisted of "certified" cases in South Wales during the

TABLE 7

EXPECTED NO. OF DEATHS AMONG MINERS AND EXMINERS WITH PNEUMOCONIOSIS AGED 50 IN THE FIRST TWO AND A HALF YEARS CALCULATED FROM STEWART AND OTHERS' (1948) FINDINGS AND COMPARED WITH THE FINDINGS FOR CATEGORIES B, C, D, AGED 45-54 IN TABLE 4

\begin{tabular}{|c|c|c|}
\hline & $\underset{\text { Deaths }}{\text { Number of }}$ & $\begin{array}{c}\text { Transformed } \\
\text { Mortality } \\
\text { Index } \psi\end{array}$ \\
\hline $\begin{array}{l}\text { Rhondda Fach (Observed) } \\
\text { England and Wales (Expected) }\end{array}$ & $\begin{array}{l}5 \\
3 \cdot 3\end{array}$ & $\begin{array}{r}23.4 \\
0.0\end{array}$ \\
\hline $\left.\begin{array}{c}\text { Stewart and } \\
\text { others }\end{array}\right\} \begin{array}{l}\text { Early stages } \\
\text { Advanced stages }\end{array}$ & $\begin{array}{r}7 \cdot 3 \\
33 \cdot 4\end{array}$ & $\begin{array}{r}51 \cdot 5 \\
242 \cdot 4\end{array}$ \\
\hline
\end{tabular}

Theoretical standard error of $\psi= \pm 28 \cdot 7$ 
period 1931-45. It seems possible that a marked bias was introduced into the results by the fact that only very disabled cases, particularly in the early period, could be certified. There is a wide scatter of pulmonary disability in each age group, and selection could produce a considerable difference to the average expectation of life. It is also possible that two other factors may have influenced the case fatality rate of complicated pneumoconiosis in comparatively recent times. Before the use of antibiotics in the treatment of the tuberculous, the prognosis in cases of complicated pneumoconiosis with tubercle bacilli in their sputum was very serious. Theodos and Gordon (1952) stated that $66 \%$ were dead in three years, and more recently Kilpatrick, Heppleston, and Fletcher (1954) found that in such cases with radiological signs of cavitation, $75 \%$ were dead in three years. In the Rhondda Fach in 1950-51 there were 10 patients with B, C, or D shadows and tubercle bacilli in their sputum of whom only one died in the next 2.6 years. If another seven had died, as seems probable had they not received chemotherapy, the S.M.R.s for this group would have been considerably higher, as shown in Table 8. Similarly, the intensive use of antibiotics in the treatment of the non-tuberculous respiratory

\section{TABLE 8}

THE S.M.R.S OF CATEGORIES B, C, AND D, ASSUMING THAT $75 \%$ OF SPUTUM-POSITIVE PATIENTS IN CATEGORIES B, C, AND D HAD ALSO DIED

\begin{tabular}{|c|c|c|c|c|}
\hline \multirow{2}{*}{$\begin{array}{c}\text { Age } \\
\text { Range }\end{array}$} & \multicolumn{4}{|c|}{ Miners and Ex-miners in Categories B, C, and D } \\
\hline & $\begin{array}{c}\text { Observed } \\
\text { Deaths }\end{array}$ & $\begin{array}{c}\text { Expected } \\
\text { Deaths }\end{array}$ & S.M.R. & $\underset{\text { Errors }}{\text { Standard }}$ \\
\hline $\begin{array}{l}20-64 \\
25-64 \\
25-74 \\
35-74\end{array}$ & $\begin{array}{l}29 \\
29 \\
54 \\
52\end{array}$ & $\begin{array}{l}15.8 \\
15.8 \\
33.9 \\
33.8\end{array}$ & $\begin{array}{l}183.5 \\
183.5 \\
159.3 \\
153.8\end{array}$ & $\begin{array}{l} \pm 34.08 \\
\pm 34.08 \\
\pm 21.68 \\
\pm 21.33\end{array}$ \\
\hline
\end{tabular}

infections, from which the cases with advanced complicated pneumoconiosis so frequently suffer, may also have influenced their case fatality.

As regards simple pneumoconiosis, one point must be stressed to avoid misunderstanding. The higher categories of simple pneumoconiosis are associated with an increased risk of developing complicated pneumoconiosis (Fletcher, 1948, Davies Fletcher, Mann, and Stewart, 1949 ; Mann 1951 ; Cochrane and others, 1951). The rate of appearance of the latter on the former is of the order of 1 to $2 \%$ per annum, so there was in our short follow-up of 2.6 years little chance of the mortality associated with simple pneumoconiosis being influenced by those patients who develop the more advanced form of complicated pneumoconiosis. This would not hold good in a long-term follow-up. Our data therefore lead to the following conclusions; there is no evidence to suggest that on the average a radiological diagnosis of simple pneumoconiosis over the age of 45 carries an increased risk of death within the next two and a half years. Individuals may, of course, be differently affected, but since the above was true for all ages we may say that simple pneumoconiosis would not appear to affect the expectation of life, provided P.M.F. did not develop, and should P.M.F. develop the reduction in expectation of life did not appear to be as marked as has sometimes been thought. Our data do not, of course, exclude the possibility of some small increase or decrease in expectation of life associated with simple pneumoconiosis.

\section{Summary}

The deaths from all causes in the Rhondda Fach between the two radiological surveys in 1950-51 and 1953 have been related to the age, sex, and occupation of those in the valley at the time of the first survey and compared with expected values derived from the Registrar General's figures for England and Wales. In the case of miners and ex-miners radiographed during the first survey, the deaths were also related to the category of pneumoconiosis found in their chest radiographs at that time. The results suggest that the more advanced forms of complicated pneumoconiosis, in the higher ages, may be associated with an excessive number of deaths. No such excess was found associated with simple pneumoconiosis, although the possibility of a small excess or deficiency could not be excluded.

This work was carried out under the general direction of the Rhondda Fach Local Advisory Committee and we should like to express our thanks to them for their help, encouragement, and advice. They are not in any way responsible, however, for the views expressed by the authors in this paper.

We should particularly like to thank the other members of the epidemiological team at the Pneumoconiosis Research Unit, who played a major part in both surveys and helped to work out the results; Dr. T. F. Jarman and his M.M.R. team who worked with us during both surveys ; Dr. C. M. Fletcher, previously Director of the Pneumoconiosis Research Unit ; Dr. J. C. Gilson, the Director ; Mr. P. D. Oldham and Dr. W. E. Miall, members of the scientific staff of the Pneumoconiosis Research Unit; the numerous officials of the National Coal Board and the National Union of Mineworkers who assisted us in the surveys ; the Cardiff Pneumoconiosis Medical Panel of the Ministry of Pensions and National Insurance, and others who lent us many films ; the Medical Officer of Health, Rhondda Borough, and his department ; and above all, the men and women of the Rhondda Fach without whose help this work would have been impossible. 


\section{A P P E N D I X}

It might be thought that there is nothing very difficult in calculating the expected number of deaths from the Registrar General's annual mortality rates. The changes in the age of the population are small, the death rates fairly constant, and the duration of the follow-up not long. Hence it might be expected that it would be all right to ignore changes in age and the fact that the size of the population followed up decreases with time owing to deaths. But a rough approach which ignores both these changes may give estimates that are too small by $14 \%$ of the expected deaths, while if we only ignore the second of these changes we increasingly overestimate the expected number of deaths, as the age of the group increases, so that in the oldest age groups our estimate will be about $50 \%$ too large. Obviously such errors must be avoided, and we therefore give an account of the computational procedure adopted and the reasons for it.

The population that we followed up in the Rhondda Fach is divided into age groups by age last birthday on January 1, 1951. The Registrar General tabulates death rates for groups based on age at the mid-year. Thus in 1951 our age groups will be six months older than the corresponding groups for which rates are tabulated. In 1952 they will be one and a half years older and in the first seven months of 19532.3 years older. The task of deriving the expected number of deaths in the Rhondda Fach then falls into two stages. The first is to derive the rates in England and Wales for 1951, 1952, and the first 0.6 of 1953 appropriate to our age groups by interpolation. The second stage is to apply these rates to the Rhondda Fach population.

If we plot out the logarithm of the death rates for England and Wales at equal intervals of age, we find that they fall on an approximately straight line. The approximation is good for the higher age groups, e.g., over 25 , on which interest is chiefly centred. Below this age the assumption that the log (rates) are linear will not lead us far astray. If, therefore, we require the death rate for a 10-year age group, different from those tabulated, the best way to derive it is by linear interpolation, or for a group older than 85 by extrapolation, on the logarithms of the tabulated rates. Death rates for five-year age groups can be derived similarly when the rates for five-year groups are tabulated.

This procedure of interpolating is based on observation of the behaviour of the tabulated death rates and avoids any assumptions about the proportions of deaths that occur at any particular age. In particular, it avoids assuming that if $\vee(65-)$ is the tabulated rate for the age group 65-74 then the proportion of deaths at age 70 is equal to $\vee(65-)$, a dangerous assumption which will only be true in special circumstances.

The Registrar General tabulates the total mid-year population and the number of deaths per month in five-year age groups. The death rates are also tabulated in five-year age groups up to the age of 25 , thereafter being tabulated in 10-year age groups. Thus, deriving rates for 1951 and 1952 for our age groups is merely a matter of linear interpolation and extrapolation with the logarithms of the tabulated rates. The only difficulty is at the changeover of the interval of tabulation. This is easily surmounted by computing the death rate for the age group 25-30. For 1953, death rates like the usual ones tabulated were worked out, based on the number of deaths in the first seven months of 1953 and divided by the mid-year population. The use of the mid-year population is an approximation which will have a negligible effect on the results. The effective rate of death operating will be this rate divided by 0.6 , the portion of the year covered.

Having derived the expected rates for each year, we have to calculate the expected number of deaths in the inter-survey period. To do this we assume the rate of death is constant in each age group throughout each year. This will be fairly accurate as the increase in rate due to age is more than offset by the decrease in rates with time, with the result that the expected rates remain remarkably constant over the inter-survey period.

Consider one such age group. In a small interval of time $\delta \tau$ at $\tau$ let

$\rho(\tau)=$ the population alive

$\delta \rho=$ the change in the population

$\nu(\tau)=$ the rate of death at time $\tau$, expressed as a proportion and not as a percentage or otherwise, per unit interval of $\tau$

Note, $\delta \rho$ in this case can only be due to death as all the original population were followed up to find out if they were still living. Then

$$
\delta \rho=-\rho(\tau) \nu(\tau) \delta \tau .
$$

Integrating with respect to $\tau$ from $\tau_{0}$ to $\tau_{1}$ we get :

$$
\begin{gathered}
\int_{\tau_{0}}^{\tau_{1}} \frac{\alpha \rho}{\rho(\tau)}=-\int_{\tau_{0}}^{\tau_{1}} \nu(\tau) \alpha \tau \\
\log \left\{\rho\left(\tau_{1}\right) / \rho\left(\tau_{0}\right)\right\}=-\nu\left(\tau_{1}-\tau_{0}\right),
\end{gathered}
$$

if $\nu(\tau)$ is constant and equal to $\nu$ in the interval $\left(\tau_{0}, \tau_{1}\right)$. That is

$$
\rho\left(\tau_{1}\right)=\rho\left(\tau_{0}\right) \exp \left\{-\nu\left(\tau_{1}-\tau_{0}\right)\right\} .
$$

In the case on hand the unit interval of time is one year. We have rates $\nu_{1}, \nu_{2}$, and $\nu_{3} / 0.6$ operating on the group from $\tau_{0}=$ January 1,1951 , to $\tau_{1}$, = January 1 , 1952, $\tau_{1}$ to $\tau_{2}=$ January 1,1953 , and $\tau_{2}$ to $\tau_{3}=$ August 1,1953 , respectively.

Then

$$
\begin{aligned}
\rho\left(\tau_{1}\right) & =\rho\left(\tau_{0}\right) \exp \left\{-\nu_{1}\right\} \\
\rho\left(\tau_{2}\right) & =\rho\left(\tau_{1}\right) \exp \left\{-v_{2}\right\} \\
\rho\left(\tau_{3}\right) & =\rho\left(\tau_{2}\right) \exp \left\{\left(-v_{3} / 0.6\right) \times c \cdot 6\right\} \\
& =\rho\left(\tau_{2}\right) \exp \left\{-\nu_{3}\right\} \\
\therefore \rho\left(\tau_{3}\right) & -\rho\left(\tau_{0}\right) \exp \left\{=\left(\nu_{1}+\nu_{2}+\nu_{3}\right)\right\}
\end{aligned}
$$

and the expected number of deaths is equal to $\rho\left(\tau_{0}\right)-\rho\left(\tau_{3}\right)=\rho\left(\tau_{0}\right)\left[1-\exp \left\{-\left(\nu_{1}+\nu_{2}+\nu_{3}\right)\right\}\right]$ 
Thus once the rates $\nu_{1}, v_{2}$ and $\nu_{3}$ have been derived we obtain the expected number of deaths in each age, sex, or occupation group by multiplication of the population by a factor. Adding the observed and the expected number of deaths for several age groups we can obtain the standardized mortality ratios (S.M.R.) for the intersurvey period for any age range.

\section{Standard Errors}

By assuming that the number of deaths each year in England and Wales is a Poisson variable we can compute the standard error of the expected number of deaths in any age group, or for the total number of deaths expected in any population. These expected numbers will be a weighted sum of Poisson variables. For the total female population in the Rhondda Fach, the standard error of the estimate of the expected number of deaths, 293.0, is less than \pm 0.6 and will be smaller for smaller groups. This is assumed to be negligible.

On the other hand, if we regard the numbers of deaths in each of the age groups that are observed as Poisson variables, the total number of deaths observed for any combination of groups will still be a Poisson variable. Hence we can deduce that the standard error of an S.M.R. will be

$$
\pm \frac{\sqrt{ }(\text { No. of deaths observed) }}{\text { No. of deaths expected }}
$$

and by using tables for the Poisson distribution we could test whether the S.M.R. is significantly different from 100 .

The assumption that the number of deaths has a Poisson distribution gives an overestimate of the variance of the S.M.R., but is sufficiently accurate to show the orders of magnitude involved, if deaths occur in a random manner, with a given expectation. The validity of this hypothesis is discussed with reference to Table 6 , where an alternative treatment of departure from expectation is given.

\section{REFERENCES}

Cochrane, A. L., Cox, J. G., and Jarman, T. F. (1952). Brit. med. J., 2,843 .

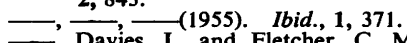

Davies, I., and Fletcher, C. M. (1951), British Journal of Industrial Medicine, 8, 244.

Fletcher, C. M., Gilson, J. C., and Hugh-Jones, P. (1951) Ibid., 8, 53.

Davies, I., Fletcher, C. M., Mann, K. J., and Stewart, A. (1949) Proc. 9th Int. Congr. on industr. Med., London, 1948, p. 773. Wright, Bristol.

Fletcher, C. M. (1948). Brit. med. J., 1, 1015, 1065

(1955). Arch. industr. Hith, 11, 17.

Gilson, J. C., and Hugh-Jones, P. (1955). Spec. Rep. Ser. med. Res. Coun. (Lond.), No. 290.

- Higgins, I. T. T., and Carpenter, R. G. (1956). In the press.

Gough, J., and Heppleston, A. G. (1955). Reported in Nature (Lond.), 176, 762 .

Kilpatrick, G.' S., Heppleston, A. G., and Fletcher, C. M. (1954). Thorax, 9, 260.

Mann, K. J. (1951). Ibid., 6, 43.

Registrar General (1936). Decennial Supplement, England and Wales, 1931. Part I. Life Tables.

Roach, S. A. (1953). British Journal of Industrial Medicine, 10, 220

Stewart, A., Davies, I., Dowsett, L., Morrell, F. H., and Pierce, J. W.' (1948). Ibid., 5, 120

Theodos, P. A., and Gordon B. (1952). Amer. Rev. Tuberc., 65, 24. 